\title{
Corpus luteum dimensions and vascularity reflect its functionality in pregnant and non-pregnant buffaloes
}

\author{
M. Gaur ${ }^{1}$ and G. N. Purohit ${ }^{2 *}$
}

${ }^{1}$ Department of Veterinary Gynecology and Obstetrics, College of Veterinary and Animal Science, Navania, Vallabhnagar, Udaipur; ${ }^{2}$ Department of Veterinary Gynecology and Obstetrics, College of Veterinary and Animal Science, Rajasthan University of Veterinary and Animal Sciences, Bikaner, Rajasthan, India 334001.

* Corresponding author email:gnpobs@gmail.com

Journal of Livestock Science (ISSN online 2277-6214) 11: 101-105

Received on 23/3/20; Accepted on 5/6/2020

doi. 10.33259/JLivestSci.2020.101-105

\begin{abstract}
With an objective to record the dimensions, vascularity changes in the corpus luteum and progesterone production in pregnant and non-pregnant buffaloes, Surti buffaloes $(n=42)$ were inseminated during natural estrus during the breeding season and scanned by transrectal B mode and color flow mode ultrasonography daily starting from Day 3, till Day 21. The CL dimensions on Day 5, 11 and 13 were significantly higher $(\mathrm{P}<0.05)$ in buffaloes that conceived compared to those that did not conceive. On Day 18, the CL diameters were significantly lower in nonpregnant buffaloes. The amount of color pixel in color Doppler evaluation of vascularity of CL showed fluctuating increase in both pregnant and non-pregnant buffaloes up to Day 14 but, thereafter a decrease was recorded. In buffaloes that did not conceive the amount of color pixel was significantly lower $(\mathrm{P}<0.05)$ and half of that in pregnant buffaloes. The plasma progesterone concentrations were synchronous to CL diameters and vascularity however, steep decrease in plasma progesterone was observed on Day 20 for non-pregnant buffaloes returning to estrus. It was concluded that the dimensions of the CL and its vascularity reflect its functionality and can be used to predict buffaloes that are likely to be non-pregnant.
\end{abstract}

Key words: Buffalo; corpus luteum; vascularity; progesterone; Color Doppler. 


\section{Introduction}

The corpus luteum (CL) is a temporary endocrine gland formed over the ovary following ovulation and secretes progesterone to regulate estrous cycle and support the establishment of pregnancy (Niswender et al., 2000). In the absence of pregnancy in cows, the CL begins to regress by Day 17-18 (Niswender et al., 2000). The functioning of bubaline CL appears to be similar to that in cattle. The progesterone concentration from bubaline CL increased gradually to peak around Day 7 and declined around Day 17-20 coinciding with CL regression (Baithalu et al., 2013). During recent years the relationship of CL diameters and vascularity in relation to plasma progesterone production has been evaluated in cows using color Doppler ultrasonography (de Tarso et al., 2017) as this can be a predictor of fertility following artificial insemination or embryo transfer (Pinaffi et al., 2015). Although one previous report found no difference in the CL vascularity in pregnant and non-pregnant cows during early pregnancy (Beindorff et al., 2010) others found that the CL vascularity provides additional information on the CL function (Luttgenau and Bollwein, 2014) and that the blood flow to the CL on Day 20 represents a quick, reliable, and consistent diagnostic test that enables the early detection of non-pregnant cattle (Siqueira et al., 2013). Moreover, Doppler echo can be used to visualize fetal loss, a situation where the blood flow to the corpus luteum decreases rapidly before the next estrus (Matsui and Miyamoto, 2009). Recently, Pugliesi et al. (2018) found that transferring embryos to cows with a higher blood perfusion and thus better functionality; resulted in higher proportion of pregnancies. A few reports on buffaloes evaluated the vascularity of CL in buffaloes (Caunce et al., 2019; Gaur and Purohit, 2019). The present study evaluated the dimensions and vascularity of CL of Surti buffaloes from Day 3 till Day 21 of insemination during natural estrus using color Doppler ultrasonography and compared them between buffaloes that were subsequently found either pregnant or non-pregnant.

\section{Materials and Methods}

Surti buffaloes $(n=42)$ belonging to the elite herd maintained at College of Veterinary and Animal Science, Navania, Vallabhnagar, Udaipur, Rajasthan, India were included in the study during the breeding season (November to March 2015-16). Estrus detection was carried out by parading a teaser buffalo bull early morning and late evening as described previously (Purohit and Rao, 2018). Buffaloes in standing estrus were inseminated twice at $12 \mathrm{~h}$ intervals with frozen semen from high fertility buffalo bulls. Buffaloes were restrained in a chute and examined by transrectal B mode and CFM mode ultrasonography daily till pregnancy confirmation at Day 30 using procedures described previously (Zambrano-Varon, 2018). The CL dimensions were recorded, and then the vascularity changes were recorded using CFM mode. The images were stored and the pixel values of color of blood were evaluated as described previously (Gaur and Purohit, 2019).

Blood was collected from buffaloes daily and plasma was separated and stored at $-20^{\circ} \mathrm{C}$ till assay. Progesterone concentration was estimated using ELISA kit (DIA source Immuno assay, Belgium) and the results were read on an Elisa reader as described previously (Gupta and Purohit, 2001). The correlation of plasma progesterone with vascularity of the CL was estimated. The inter- and intra-assay coefficient of variation was less than $10 \%$.

\section{Correlation of $\mathrm{CL}$ characteristics and fertility}

The relationship between the CL characteristics (CL dimension, pixel values of blood flow and the plasma progesterone concentrations) on different days of estrous cycle were compared between the buffaloes that were subsequently found to be pregnant or non-pregnant to find the relationship between CL characteristics and fertility if any.

\section{Statistical analysis}

Statistical computations and data analysis was done as per standard methods mentioned previously and described in standard text (Snedecor and Cochran, 1994).

\section{Results}

For the buffaloes studied 20 buffaloes were confirmed pregnant on Day 30, eight buffaloes returned to estrus on Day 21-23 and 14 buffaloes did not return to estrus but were found non-pregnant on Day 30. The results of 20 pregnant and 22 non-pregnant buffaloes have been presented.

\section{CL dimensions}

The CL dimensions (Fig. 1) on all days of evaluation in Surti buffaloes that were subsequently found to be pregnant were higher compared to buffaloes that were non-pregnant. Significantly higher $(\mathrm{P}<0.05) \mathrm{CL}$ dimensions were recorded in pregnant buffaloes on Day $5(15.84 \pm 0.61 \mathrm{~mm})$, Day $11(20.54 \pm 0.48 \mathrm{~mm})$, Day $13(23.26 \pm 0.11$ $\mathrm{mm})$ and Day $18(23.72 \pm 0.54 \mathrm{~mm})$ compared to non pregnant buffaloes $(11.78 \pm 0.41 \mathrm{~mm}, 16.25 \pm 0.37 \mathrm{~mm}$, $19.38 \pm 0.36 \mathrm{~mm}$ and $10.70 \pm 0.19 \mathrm{~mm}$ on Days 5, 11, 13 and 18 respectively). 


\section{Blood flow to $\mathbf{C L}$}

The pixel values for blood flow to the $\mathrm{CL}$ was significantly higher $(\mathrm{P}<0.01)$ on Day $5(1174.6 \pm 112.30)$ and Day $13(2563.6 \pm 196.54)$ of the estrous cycle in pregnant buffaloes (Table 1, Fig. 2) compared to non pregnant buffaloes $(689.4 \pm 54.12$ and $1820.25 \pm 137.94)$. In pregnant buffaloes the pixel values increased slightly on Day 15 (3196.2 \pm 310.41$)$ and then declined. However, in non-pregnant buffaloes the pixel values were significantly high on Day 15 (3247.8 \pm 256.32$)$ followed by a precipitous decline on Day $16(1432 \pm 114.21)$ that continued till Day 19 (210.21 \pm 38.96$)$ of the estrous cycle. On Day 18 the fall in blood supply in non-pregnant buffaloes was significantly higher $(\mathrm{P}<0.05)$ compared to pregnant buffaloes.

\section{Plasma progesterone}

Plasma progesterone concentrations in pregnant Surti buffaloes were significantly higher $(\mathrm{P}<0.05)$ compared to non-pregnant buffaloes on different days of the estrous cycle. Plasma progesterone on Day 5, Day 9 and Day 13 were $0.96 \pm 0.04 \mathrm{ng} / \mathrm{mL}$ and $0.65 \pm 0.04 \mathrm{ng} / \mathrm{mL}, 2.64 \pm 0.09 \mathrm{ng} / \mathrm{mL}$ and $2.27 \pm 0.10 \mathrm{ng} / \mathrm{mL}$ and $4.79 \pm 0.09 \mathrm{ng} / \mathrm{mL}$ and $4.09 \pm 0.08 \mathrm{ng} / \mathrm{mL}$ in pregnant and non-pregnant buffaloes respectively. In pregnant buffaloes the plasma progesterone concentrations were maintained above $1 \mathrm{ng} / \mathrm{mL}$ throughout the 21 days of the estrous cycle whereas in non pregnant buffaloes significant decline in plasma progesterone was observed on Day $17(1.46 \pm 0.15 \mathrm{ng} / \mathrm{mL}) \mathrm{and}$ the decline continued to reach lowest values $(0.26 \pm 0.08 \mathrm{ng} / \mathrm{ml})$ on Day 20 of the estrous cycle. On Day 20 the progesterone concentrations were significantly higher $(\mathrm{P}<0.05)$ in pregnant buffaloes compared to non-pregnant buffaloes.

It was thus noticed that the characteristics of the CL (dimension and blood supply) were significantly related with functionality (progesterone concentration) in Surti buffaloes.

Table 1 Comparison between pregnant and non- pregnant Surti buffaloes for different parameters of corpus luteum

\begin{tabular}{|l|l|l|l|l|l|l|}
\hline $\begin{array}{l}\text { Days } \\
\text { of } \\
\text { Estrus }\end{array}$ & \multicolumn{2}{|c|}{ CL diameter (mm) } & \multicolumn{2}{c}{ Amount of colour Pixel } & \multicolumn{2}{c|}{$\begin{array}{l}\text { Progesterone conc } \\
\text { ng/mL }\end{array}$} \\
\hline & Pregnant & Non-Pregnant & Pregnant & Non-Pregnant & Pregnant & Non-Pregnant \\
\hline 3 & $13.50 \pm 0.41$ & $11.21 \pm 0.33$ & $689.4 \pm 54.12^{\mathrm{a}}$ & $443 \pm 62.51^{\mathrm{b}}$ & $0.52 \pm 0.05$ & $0.45 \pm 0.01$ \\
\hline 4 & $14.72 \pm 0.54$ & $12.95 \pm 0.23$ & $712.8 \pm 63.24$ & $686.75 \pm 74.51$ & $0.65 \pm 0.04$ & $0.56 \pm 0.03$ \\
\hline 5 & $15.84 \pm 0.61^{\mathrm{a}}$ & $11.78 \pm 0.41^{\mathrm{b}}$ & $1174.6 \pm 112.30$ & $1013.5 \pm 152.36$ & $0.96 \pm 0.04^{\mathrm{a}}$ & $0.65 \pm 0.04^{\mathrm{b}}$ \\
\hline 6 & $16.54 \pm 0.23$ & $14.38 \pm 0.26$ & $783.4 \pm 85.32$ & $655 \pm 78.45$ & $0.92 \pm 0.03$ & $0.83 \pm 0.06$ \\
\hline 7 & $17.58 \pm 0.41$ & $15.41 \pm 0.25$ & $1657.4 \pm 163.24$ & $1438.75 \pm 101.21$ & $1.33 \pm 0.11$ & $1.24 \pm 0.10$ \\
\hline 8 & $18.35 \pm 0.35$ & $17.66 \pm 0.42$ & $1710 \pm 142.31$ & $1666.5 \pm 156.45$ & $1.76 \pm 0.12$ & $1.60 \pm 0.13$ \\
\hline 9 & $19.86 \pm 0.34$ & $17.18 \pm 0.31$ & $1759.4 \pm 132.61$ & $1515 \pm 164.51$ & $2.64 \pm 0.09^{\mathrm{a}}$ & $2.27 \pm 0.10^{\mathrm{b}}$ \\
\hline 10 & $19.84 \pm 0.29$ & $18.75 \pm 0.46$ & $2162.6 \pm 158.23$ & $1820.25 \pm 137.94$ & $3.22 \pm 0.35$ & $3.20 \pm 0.36$ \\
\hline 11 & $20.54 \pm 0.48^{\mathrm{a}}$ & $16.25 \pm 0.37^{\mathrm{b}}$ & $2563.6 \pm 196.54$ & $2269.75 \pm 214.65$ & $3.47 \pm 0.34$ & $3.18 \pm 0.33$ \\
\hline 12 & $20.34 \pm 0.36$ & $18.30 \pm 0.22$ & $2929.8 \pm 263.14$ & $2626.75 \pm 197.69$ & $4.73 \pm 0.17^{\mathrm{a}}$ & $4.14 \pm 0.12^{\mathrm{b}}$ \\
\hline 13 & $23.26 \pm 0.11^{\mathrm{a}}$ & $19.38 \pm 0.36^{\mathrm{b}}$ & $3196.2 \pm 310.41$ & $2669.25 \pm 206.54$ & $4.79 \pm 0.09^{\mathrm{a}}$ & $4.19 \pm 0.08^{\mathrm{b}}$ \\
\hline 14 & $21.19 \pm 0.19$ & $19.68 \pm 0.31$ & $3247.8 \pm 256.32$ & $3224 \pm 254.60$ & $4.78 \pm 0.41$ & $4.56 \pm 0.51$ \\
\hline 15 & $19.94 \pm 0.11$ & $17.50 \pm 0.24$ & $1397 \pm 117.84$ & $1432 \pm 114.21$ & $5.10 \pm 0.52$ & $5.14 \pm 0.47$ \\
\hline 16 & $18.18 \pm 0.18$ & $17.03 \pm 0.29$ & $465.6 \pm 89.36$ & $418.25 \pm 74.51$ & $4.45 \pm 0.45$ & $4.28 \pm 0.51$ \\
\hline 17 & $15.66 \pm 0.26$ & $14.63 \pm 0.34$ & $264 \pm 52.32$ & $275.75 \pm 41.74$ & $3.32 \pm 0.48$ & $3.39 \pm 0.51$ \\
\hline 18 & $16.72 \pm 0.54^{\mathrm{a}}$ & $11.70 \pm 0.19^{\mathrm{b}}$ & $411.6 \pm 36.42^{\mathrm{a}}$ & $210.21 \pm 38.96^{\mathrm{b}}$ & $1.52 \pm 0.12$ & $1.46 \pm 0.15$ \\
\hline 19 & $15.88 \pm 0.41$ & $13.75 \pm 0.24$ & $192.6 \pm 36.21$ & $179.75 \pm 23.41$ & $1.74 \pm 0.08^{\mathrm{a}}$ & $0.66 \pm 0.11^{\mathrm{b}}$ \\
\hline 20 & $15.28 \pm 0.33$ & $13.34 \pm 0.51$ & $185.8 \pm 30.20$ & $177 \pm 31.20$ & $1.65 \pm 0.02^{\mathrm{a}}$ & $0.26 \pm 0.08^{\mathrm{b}}$ \\
\hline 21 & $14.10 \pm 0.20$ & $13.06 \pm 0.48$ & $239 \pm 32.21$ & $214 \pm 22.19$ & $1.42 \pm 0.02$ & $0.23 \pm 0.31$ \\
\hline & & & & & & \\
\hline
\end{tabular}

\section{Discussion}

Values with different superscripts in a row are significantly different $(\mathrm{P}<0.05)$.

The CL diameters increased sequentially both in pregnant and non-pregnant buffaloes till Day 13 of estrus, thereafter the diameters decreased slightly. Comparison of CL diameters in pregnant buffaloes on Day 5, 11, 13 and 18 revealed significantly $(\mathrm{P}<0.05)$ higher $\mathrm{CL}$ dimensions compared to non-pregnant buffaloes. Similar to the present study, Lasheen et al., (2018) recorded increase in CL diameters in pregnant buffaloes yet in non-pregnant buffaloes the CL dimensions started declining from Day 18 of gestation. A previous study on lactating Holstein cows (Ricci et al., 2017) observed that cows that maintained their CL beyond Day 21 are those that underwent embryonic losses. The plasma progesterone concentration increased sequentially both in pregnant and non-pregnant buffaloes up to Day 15. The progesterone concentrations were significantly $(\mathrm{P}<0.05)$ higher in pregnant buffaloes compared to nonpregnant buffaloes on Day 5, 9, 12, 13 and 19. Similar increase in plasma progesterone was recorded in pregnant and non-pregnant buffaloes (Batra et al., 1979; Perera et al., 1980; Kamboj and Prakash, 1993; Gupta and Purohit, 2001). A significant $(\mathrm{P}<0.05)$ fall in plasma progesterone was observed in non-pregnant buffaloes on Day 19 and 20 of 
estrus reflecting luteolysis. Studies on buffaloes have shown that luteolysis in buffaloes occurs between Day 18-20 (Mondal et al., 2004; Mondal et al., 2007).

The blood flow to the CL increased with fluctuations to reach a peak on Day 14, both in pregnant and nonpregnant buffaloes. A previous study observed a precipitous fall in blood flow to the CL in buffaloes during a natural estrous cycle (Gaur and Purohit, 2019). From Day 15 the blood flow to the CL started declining. The blood flow to the $\mathrm{CL}$ was significantly higher $(\mathrm{P}<0.05)$ in pregnant buffaloes on Day 18 compared to non-pregnant buffaloes. Similar findings have been recorded in previous studies on cattle (Beindorff et al., 2010; Siqueira et al., 2013) and buffalo (Lasheen et al., 2018).

The changes in CL dimensions and vascularity were synchronous to plasma progesterone reflecting that the vascularity of CL changes in relation to its functionality in buffaloes during early pregnancy and corroborates with previous findings in cattle (Beindorff et al., 2010; de Tarso et al., 2017; Lasheen et al., 2018; Gaur and Purohit, 2019). It was concluded that the dimensions of the CL and its vascularity reflect its functionality and can be used to predict buffaloes that are likely to be non-pregnant.

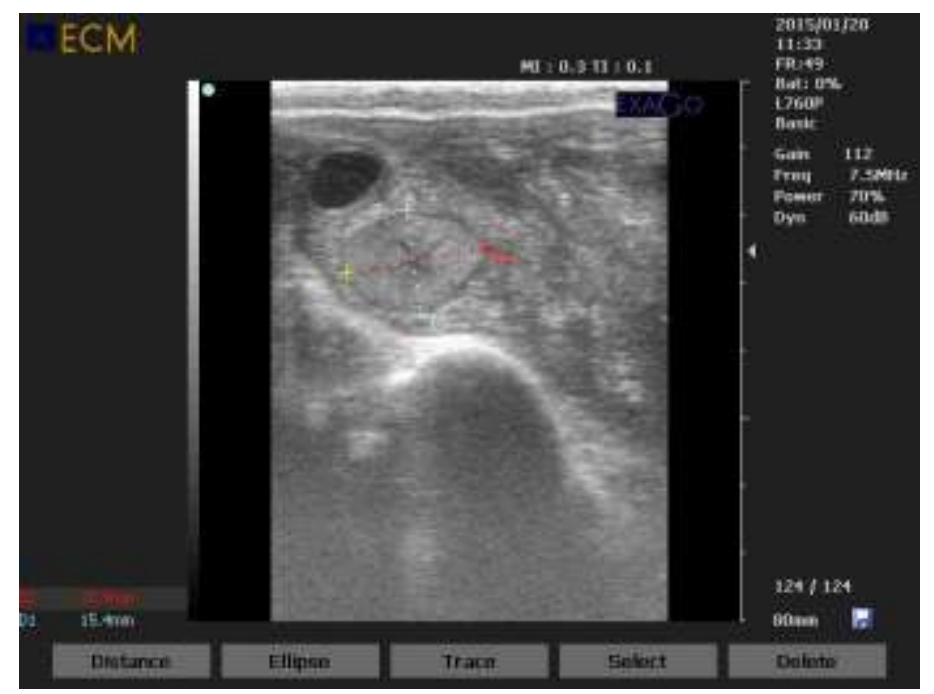

Fig 1. The dimension of a CL. A follicle is also visible.

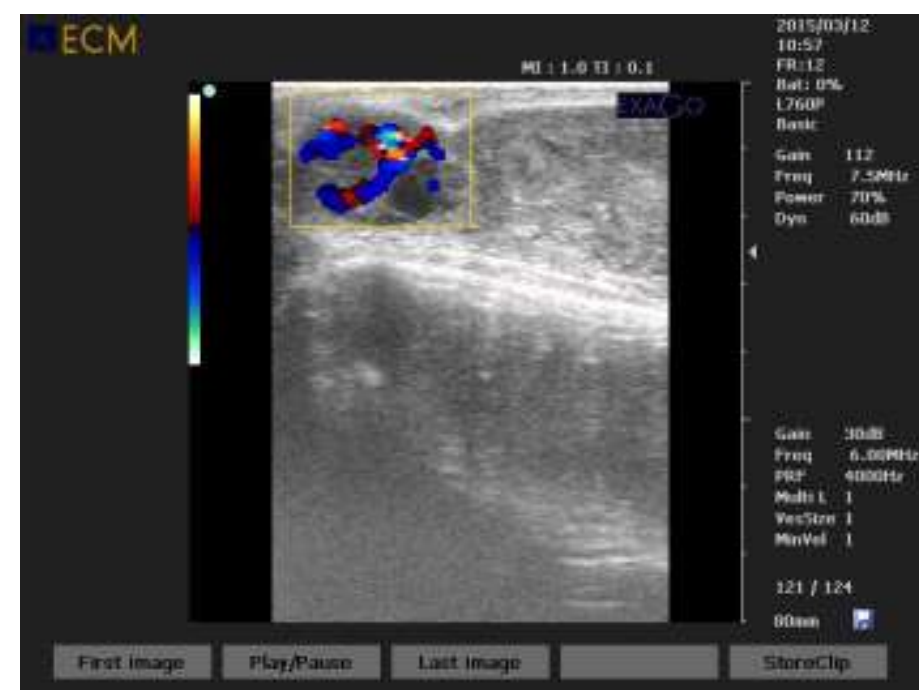

Fig. 2 Colour Doppler sonogram of a Surti buffalo corpus luteum (CL) on Day 13 of the estrous cycle showing high vascularity. 


\section{References}

1) Baithalu RK, Singh SK, Gupta C, Raja AK,Saxena A, Kumar Y, Singh R, Agarwal SK, 2013. Cellular and functional characterization of buffalo (Bubalus bubalis) corpus luteum during the estrous cycle and pregnancy. Animal Reproduction Science 140: 138-146.

2) Batra SK, Arora RC, Bachlaus NK, Pandey RS, 1979. Blood and milk progesterone in pregnant and non-pregnant buffalo. Journal of Dairy Science 62(9): 1390-1393.

3) Beindorff N, Nagai K, Shirasuma K, Herzog K, Hoefmann K, Sasaki M, Bollwein H, Miyamoto A, 2010. Vasccular changes in the corpus luteum during early pregnancy in the cow. Journal of Reproduction and Development 56(2): 263-270.

4) Caunce SL. Dadarwal D, Adams GP, Brar P, Singh J, 2019. An objective volumetric method for assessment of ovarian follicular and luteal vascular flow using colour Doppler ultrasonography. Theriogenology 138: 6676.

5) de Tarso SGS, Gastal GDA, Bashir ST, Gastal MO, Apgar GA, Gastal EL, 2017. Follicle vascularity coordinates corpus luteum blood flow and progesterone production. Reproduction Fertility and Development 29: 448457.

6) Gaur M, Purohit GN, 2019. Follicular dynamics and colour Doppler vascularity evaluations of follicles and corpus luteum in relation to plasma progesterone during the oestrous cycle of Surti buffaloes. Reproduction in Domestic Animals 54(3): 585-594.

7) Gupta KA, Purohit GN, 2001. Use of vaginal electrical resistance (VER) to predict estrus and ovarian activity, its relationship with plasma progesterone and its use for insemination in buffaloes. Theriogenology 56(2): 235245.

8) Kamboj M, Prakash BS, 1993. Relationship of progesterone in plasma and whole milk of buffaloes during cyclicity and early pregnancy. Tropical Animal Health and Production 25(3): 185-192.

9) Lasheen ME, Badr HM, Kandiel MMM, ElMaty AAM, Samir H, Farouk M, Eldawy AH, 2018. Predicting early pregnancy in Egyptian buffalo cows via measuring uterine and luteal blood flows, and serum and saliva progesterone. Tropical Animal Health and Production 50: 137-142.

10) Lüttgenau J, Bollwein H, 2014. Evaluation of bovine luteal blood flow by using color Doppler ultrasonography. Reproductive Biology 14(2): 103-109.

11) Matsui M, Miyamoto A, 2009. Evaluation of ovarian blood flow by colour Doppler ultrasound: practical use for reproductive management in the cow. Veterinary Journal 181: 232-240.

12) Mondal S, Kumar V, Reddy IJ, Singh K, 2004. Progesterone and nucleic acid content of buffalo corpus luteum in relation to stages of oestrous cycle. Indian Journal of Animal Science 74(6): 710-712

13) Mondal S, Prakash BS, Palta P, 2007. Endocrine aspects of oestrous cycle in buffaloes (Bubalus bubalis): An overview. Asian-Australasian Journal of Animal Science 20(1): 124-131.

14) Niswender GD, Juenge JL, Silva PJ, Rollyson MK, Mc Intush EW, 2000. Mechanisms controlling the function and life span of the corpus luteum. Physiological Reviews 80: 1-29.

15) Perera BM, Pathiraja N, Abeywardena SA, Motha MX, Abeygunawardena H, 1980. Early pregnancy diagnosis in buffaloes from plasma progesterone concentration, Veterinary Record 106(5): 104-106.

16) Pinaffi FLV, Santos ES, da Silva MG, Filho MM, Mdaureira EM, Silva LA, 2015. Follicle and corpus luteum size and vascularity as predictors of fertility at the time of artificial insemination and embryo transfer in beef cattle. Pesqueisa Veterinaria Brsileira 35(5): 470-476.

17) Pugliesi G, deMelo GD, Ataide GA, Pellegrino CAG, Silva JB, Rocha CC, Motta IG, Vasconcelos JLM, Binelli M, 2018. Use of Doppler ultrasonography in embryo transfer programs: feasibility and field results. Animal Reproduction 15(3): 239-246.

18) Purohit GN, Rao TKS, 2018. Estrus Detection in Buffaloes. In: GN. Purohit (Ed.), Bubaline Theriogenology. Ithaca, NY: International Veterinary Information Service 1-26.

19) Ricci A, Carvalho PD, Amundson AC, Fricke PM, 2017. Characterization of luteal dynamics in lactating Holstein cows for 32 days after synchronization of ovulation and timed artificial insemination. Journal of Dairy Science 100: 9851-9860.

20) Siqueira LG, Areas VS, Ghetti AM, Fonseca JF, Palhao MP, Fernandes CA, Viana JH, 2013. Color Doppler flow imaging for the early detection of non-pregnant cattle at 20 days after timed artificial insemination. Journal of Dairy Science 96(10): 6461-6472.

21) Snedecor GW, Cochran WG, 1994. Statistical Methods. $8^{\text {th }}$ edition Iowa State University Press, Iowa, USA.

22) Zambrano-Varon GJ, 2015. Reproductive application of ultrasound in the female buffalo (Bubalus bubalis). In GN. Purohit (Ed.), Bubaline Theriogenology, Ithaca, NY: International Veterinary Information Service. Last updated: 18-Dec-2015; A5709.1215 page 1-18. 